Sains Malaysiana 50(5)(2021): 1433-1444

http://doi.org/10.17576/jsm-2021-5005-22

\title{
Study on the Mechanism of Ginkgo Seeds in Treating Bronchitis by Network Pharmacology
}

(Kajian terhadap Mekanisme Biji Ginkgo dalam Rawatan Bronkitis menggunakan Rangkaian Farmakologi)

\author{
Tingting Wu, Lihu Zhang, Dongdong Li, TAO Wu, YAn JiAng* \& Linguo ZhaO*
}

\begin{abstract}
In recent years, with the global environmental deterioration and air pollution, the incidence of bronchitis has increased year by year, and the sales of anti-bronchitis drugs are growing rapidly, mainly due to the long treatment cycle and the difficulty of curing. Developing available traditional Chinese medicines with significant curative effect against bronchitis would be a promising strategy; for instance, Ginkgo seeds, as the fruit of natural plant ginkgo, has been used in ancient times to cure coughs. However, the detailed mechanism of curing cough has not been shown yet. Investigate the mechanism of Ginkgo seeds in the treatment of bronchitis by establishing a series of molecular networks including active ingredients-targets, proteins interactions, biological functions, pathway, and biological processes of targets. In this study, the main active ingredients of Ginkgo seeds and the potential targets related to bronchitis could be obtained by retrieving corresponding database. The molecular docking study between active molecules and protein targets was performed by Glide 6.6. Subsequently, a total of forty potential targets were manually selected. Based on this, the ingredients-target network was constructed using Cytoscape software, as well as proteins interactions network combing with the String database. Finally, the molecular biological function, metabolic pathway, and biological processes of these forty targets were analyzed by Clue GO plug-in. The results indicated that these protein targets were closely related to lipid transport, positive regulation of DNA replication, CAMP metabolic pathway, and other processes, which played a vital role in the treatment of bronchitis by mediating interleukin 17, fluid shear stress and atherosclerosis, asthma, renin secretion, p53, and other signaling pathways. Among these targets, the two protein ALB (Albumin) and DHRS2 (Dehydrogenase 2) can interact with compounds more frequently, and the top three compounds ranked by the docking scores were amentoflavone, (+)-catechin-5-O-glucoside, and liquiritin, implying that these compounds might be used for the treatment of bronchitis. It is obvious that the pharmacological effect of Ginkgo seeds on bronchitis displayed a characteristic of multi-components, multi-targets, and multi-pathways. Nevertheless, the two protein targets and three compounds derived from Ginkgo seeds could be further used for the explanation for Ginkgo seeds in curing bronchitis. This research can provide a scientific basis for studying on the anti-bronchitis mechanism of Ginkgo seeds.
\end{abstract}

Keywords: Bronchitis; Ginkgo seeds; mechanism; molecular docking; network pharmacology

\section{ABSTRAK}

Dalam beberapa tahun kebelakangan ini, dengan kemerosotan alam sekitar global dan pencemaran udara, penyakit bronkitis telah meningkat dari tahun ke tahun dan penjualan ubat-ubatan anti-bronkitis semakin pesat, terutamanya disebabkan oleh kitaran rawatan yang panjang dan kesukaran merawat. Pembangunan ubat-ubatan tradisi Cina yang sedia ada dengan kesan penyembuhan yang ketara terhadap bronkitis merupakan strategi yang baik, sebagai contoh, biji Ginkgo, buah semula jadi Ginkgo, telah digunakan dari zaman purba untuk mengubati batuk. Walau bagaimanapun, mekanisme yang terperinci bagi mengubati batuk belum dilaporkan. Mekanisme dalam rawatan bronkitis dikaji dengan menubuhkan satu siri rangkaian molekul, termasuk bahan-bahan aktif sasaran, interaksi protein, fungsi biologi, laluan dan proses biologi sasaran. Dalam kajian ini, bahan-bahan aktif utama biji Ginkgo dan sasaran yang berpotensi berkaitan dengan bronkitis telah diperoleh dengan mendapatkan semula pangkalan data yang sepadan. Kajian dok molekul antara molekul aktif dan sasaran protein dilakukan dengan menggunakan Glide 6.6. Seterusnya, sejumlah empat puluh sasaran yang berpotensi dipilih secara manual. Berdasarkan ini, rangkaian bahan-bahan sasaran telah dibina menggunakan perisian Cytoscape, serta rangkaian interaksi protein yang menggabungkan pangkalan data rentetan. Akhirnya, fungsi biologi molekul, laluan metabolik dan proses biologi sasaran empat puluh ini telah dianalisis oleh Clue GO plug-in. Keputusan kami menunjukkan bahawa potensi sasaran bronkitis berkaitan dengan bahan aktif biji Ginkgo memainkan peranan penting dalam rawatan bronkitis oleh mediating interleukin-17, tekanan ricih cecair dan aterosklerosis, asma, rembesan, p53 dan lain-lain laluan Sign. Antara sasaran tersebut, kedua-dua protein ALB (Albumin) dan DHRS2 (Dehydrogenase 2) boleh berinteraksi dengan sebatian dengan lebih kerap dan tiga sebatian teratas yang disenaraikan oleh skor dok adalah amentoflavone, (+)-catechin-5-O-glucoside dan liquiritin, membayangkan bahawa 
sebatian ini mungkin digunakan untuk rawatan bronkitis. Adalah jelas bahawa kesan farologi biji Ginkgo pada bronkitis memaparkan ciri pelbagai komponen, pelbagai sasaran dan pelbagai laluan. Walau bagaimanapun, dua protein sasaran dan tiga kompaun yang diperoleh daripada biji Ginkgo boleh diguna pakai untuk menjelasan peranan biji Ginkgo dalam mengubati bronkitis. Kajian ini boleh menyediakan asas saintifik untuk mempelajari mekanisme anti-bronkitis biji Ginkgo.

Kata kunci: Biji Ginkgo; bronkitis; dok molekul; mekanisme; rangkaian farmakologi

\section{INTRODUCTION}

Bronchitis is a common and frequently-occurring disease, the clinical characteristics of which are persistent cough and asthma. Ginkgo seeds has been used for the treatment of bronchitis since ancient times. According to Li Shizhen's 'Compendium of Materia Medica', Ginkgo seeds tastes bitter and has the function of moistening lung and relieving cough. Modern medical research shows that Ginkgo seeds has various pharmacological activities including sterilization, cough relief, phlegm elimination, and lung tonifying ( $\mathrm{Li}$ et al. 2017). The chemical components of Ginkgo seeds are so complex that it is difficult to explain exactly which component is working or what components are working together. Accordingly, it's hard to figure out the synergistic effect or molecular mechanism between targets and components because of its multi-component and multi-target problems in the treatment of bronchitis.

Network pharmacology can construct a molecular biological network between drugs and targets, showing the relationships of drugs-targets and the biological significance of each node. It covers several disciplines including biology, bioinformatics, and pharmacology, which not only demonstrate the complicated interactions among genes, proteins, and metabolites associated with diseases at a network level, but also coincides with the holistic and systemic views of traditional Chinese medicine (TCM) theory (Zhuang et al. 2018). Network pharmacology can combine the biological system network with drug-target network from the perspective of multitarget (Westerhoff 2015), which is beneficial for solving the problem of multi-target and multi-component mentioned before. Therefore, in this study, Ginkgo seeds was selected as the research object, and based on network analysis between components, targets, and pathways, the key targets of ingredients derived from Ginkgo seeds used for the treatment of bronchitis was systematically predicted and shown. This would provide scientific basis for further study of the mechanism of Ginkgo seeds in curing bronchitis. Moreover, the whole flowchart by network pharmacology was displayed in Figure 1.

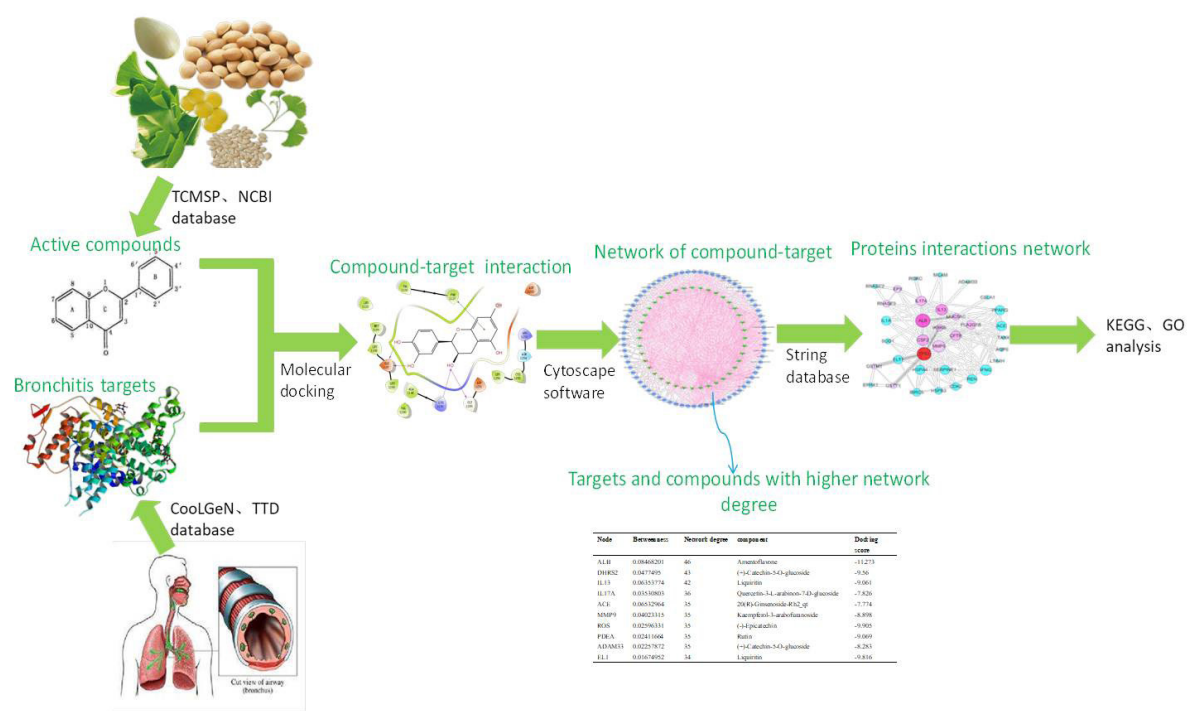

FIGURE 1. The flowchart of network pharmacology in this study 


\section{MATERIALS AND METHODS}

\section{COLLECTION AND PROCESSING OF GINKGO SEEDS COMPONENTS}

The chemical ingredients of Ginkgo seeds were obtained by searching the two known bioinformatic database, NCBI (National Center of Biotechnology Information) database (Stover \& Cavalcanti 2014) (https://www.ncbi. nlm.nih.gov/) and TCMSP (Traditional Chinese Medicine Systems Pharmacology) (Ru et al. 2014) database (http:// ibts.hkbu.edu.hk/LSP/tcmsp.php). A total of 88 small molecules were recorded and collected. After downloaded from the PubChem database, these compounds were saved as the SDF format, subsequently being prepared by the ligand preparation module. The energy minimization of these compounds was performed under the force field of OPLS2005 (Zhang et al. 2018). After preparation, these molecules were imported into the Canvas 3.1 module of Schrodinger (2015) software to calculate a series of physicochemical molecular descriptors such as the number of chiral centers, number of hydrogen bond donors, molar refractive index, number of hydrogen bond receptors, number of rotational bonds, number of aromatic rings, relative molecular weight, polar area of molecules, and lipid-water partition coefficient. All the compounds were further filtered by Lipinski's 'five principles of drugs', which can be stated as follows: the number of hydrogen- bonded receptors should be less than 10; the number of rotatable bonds should be less than 10; the relative molecular weight should be less than 500; the lipid-water partition coefficient should be less than 5; the number of hydrogen-bonded donors should be less than 5 .

\section{COLLECTION OF PROTEIN TARGETS RELATED TO BRONCHITIS}

It is well known that drug need to interact with specific targets to regulate their transcriptional level or biological activity, thus exhibiting its pharmacological effect. Therefore, in order to elucidate the mechanism of drug action, the collection of protein targets is an indispensable part for the study of the interaction between ingredients and targets. The corresponding targets in this paper are mainly obtained from the following databases: the target proteins of bronchitis drugs approved by the US FDA (Food and Drug Administration) from the CooLGeN (Human Gene Function and Network Analysis) database (http://ci.smu.edu.cn/CooLGeN/) (Zhang et al. 2017) and TTD (Therapeutic Target Database) database (https:// db.idrblab.org/ttd/) (Zhu et al. 2012); Targets associated with bronchitis derived from the TCMSP database. Combining with data mining of bronchitis literatures, a total of 44 protein targets were finally collected. In addition, the corresponding human protein targets were downloaded from the PDB (Protein Data Bank) database, as shown in Table 1.

TABLE 1. Target proteins related to bronchitis

\begin{tabular}{ccc}
\hline Target gene & Name & PDB ID \\
\hline ACE & Angiotensin-I Converting Enzyme & $4 \mathrm{BZS}$ \\
ALB & Albumin & $4 Z 69$ \\
BIRC5 & Baculoviral IAP repeat-containing protein 5 & $3 \mathrm{UEC}$ \\
CDK2 & Cell division protein kinase 2 & $5 \mathrm{NEV}$ \\
CFTR & Cystic fibrosis transmembrane conductance regulator & $5 \mathrm{D} 3 \mathrm{~F}$ \\
CSF2 & Macrophage colony-stimulating factor & $5 \mathrm{C} 7 \mathrm{X}$ \\
DRD2 & D(2) dopamine receptor & $6 \mathrm{CM} 4$ \\
ELA1 & Elastase1 & $5 \mathrm{CXA}$ \\
GSTM1 & Glutathione S-transferase M1 & $4 \mathrm{HJ} 2$ \\
HSPA4 & Heat shock protein HSP 90 beta & $5 \mathrm{FWP}$ \\
IFN- $\gamma$ & Interferon-gamma & $4 \mathrm{MZT}$ \\
IL-1 & Interleukin-1 & $5 \mathrm{AR5}$ \\
IL-13 & Interleukin-13 & $5 \mathrm{APH}$ \\
KANTR & KDM5C adjacent non-coding transcript & $3 \mathrm{RLP}$ \\
LTA4H & Leukotriene A-4 hydrolase & $5 \mathrm{BPP}$ \\
MMP9 & Matrix metalloproteinase-9 & $4 \mathrm{H} 3 \mathrm{X}$
\end{tabular}




\begin{tabular}{|c|c|c|}
\hline MUC5AC & Mucin 5AC & 5AJP \\
\hline NF-KB & Nuclear factor kappa-B & 4IDT \\
\hline PAI1 & Plasminogen activator inhibitor 1 & $4 \mathrm{AQH}$ \\
\hline PDE4 & Phosphodiesterase isozyme 4 & 5WQA \\
\hline PDEA & cAMP-specific 3',5'-cyclic phosphodiesterase A & 3V9B \\
\hline PLA2 & phospholipase A2 & $5 \mathrm{G} 3 \mathrm{~N}$ \\
\hline PPARG & Peroxisome proliferator-activated receptor gamma & $5 \mathrm{HZC}$ \\
\hline REN & Renin & $5 \mathrm{SXN}$ \\
\hline RNASE3 & Ribonuclease 3 & $2 \mathrm{LVZ}$ \\
\hline ROR- $\gamma$ & Nuclear receptor ROR-gamma & $5 \mathrm{C} 4 \mathrm{~T}$ \\
\hline STAT & Signal transducer and activator of transcription & $3 \mathrm{ZMM}$ \\
\hline VEGFR1 & Vascular endothelial growth factor receptor 1 & 5EW3 \\
\hline ADAM33 & A disintegrin and metalloproteinase domain 33 & 2FV9 \\
\hline AQP5 & Aquaporin-5 & 3D9S \\
\hline DHRS2 & Dehydrogenase 2 & $5 \mathrm{~L} 7 \mathrm{~T}$ \\
\hline EGR3 & Early growth response 3 & $5 \mathrm{IH} 8$ \\
\hline EPHX1 & Epoxide hydrolase 1 & 5IA1 \\
\hline EPX & Eosinophil peroxidase & $4 \mathrm{TWO}$ \\
\hline GSTT1 & Glutathione S-transferase theta 1 & 2C3Q \\
\hline HSPB3 & Heat shock protein family B member 3 & $5 \mathrm{AQH}$ \\
\hline IKKB & Inhibitor of nuclear factor kappa-B kinase subunit beta & $4 \mathrm{KIK}$ \\
\hline MCAM & Melanoma cell adhesion molecule & $1 \mathrm{R} 6 \mathrm{~T}$ \\
\hline NK2R & Neurokinin 2 receptor antibody & $3 \mathrm{HN} 4$ \\
\hline RNASE2 & Ribonuclease 2 & $5 \mathrm{E} 13$ \\
\hline ROS & Receptor tyrosine kinase & $5 \mathrm{FTO}$ \\
\hline SOD1 & Superoxide dismutase 1 & $4 \mathrm{~A} 7 \mathrm{~T}$ \\
\hline TP53 & Mutant tumor protein 53 & $5 \mathrm{HMH}$ \\
\hline IL-17A & Interleukin-17A & $5 \mathrm{HI} 3$ \\
\hline
\end{tabular}

\section{MOLECULAR DOCKING STUDY}

Glide 6.6 software was used for molecular docking study between the active components of Ginkgo seeds and the protein targets of bronchitis. In Maestro 11.1, Ginkgo seeds components ( 88 kinds of small molecules) were imported and prepared by ligand preparation module. The crystal structures of the human receptor protein downloaded from the PDB database were imported into the protein preparation module of Maestro 11.1. These target proteins were hydrogenated, modified, and dehydrated by default parameters, and meanwhile removing the ligands at the binding pocket of the protein crystal structures as the docking lattice (radius $<10 \AA$ ). The residues and tautomerism of ionic state were optimized in $\mathrm{pH}$ neutral state. The 88 components of Ginkgo seeds were docked according to standard precision (SP). On the other hand, the conformation search of the existing inhibitors in the protein crystal structure was not carried out. The sampling option was set as 'None (score in place only)' and only scoring operation was performed. The active site was defined according to the location of the inhibitor in the protein crystal, and the lattice box was set to: $x=2 \times 10^{-9}$ $\mathrm{m}, \mathrm{y}=2 \times 10^{-9} \mathrm{~m}, \mathrm{z}=2 \times 10^{-9} \mathrm{~m}$. All the other parameters were set to default. 


\section{NETWORK CONSTRUCTION AND ANALYSIS}

The 1080 pairs of components and target proteins with the docking score of over 6.0 were selected, containing 40 target proteins and 72 components. The protocol of network construction was presented in the following ways: Firstly, Ginkgo seeds components and bronchitis receptor target proteins were imported into Cytoscape 3.2.1 software to construct an interacting molecule-target network (Kohl et al. 2011). Among them, Ginkgo seeds molecules and bronchitis receptor target proteins were both represented by nodes, and the interactions between them were described by edge. The network analyzer plugin in the software can analyze the characteristic parameters (network degree, interval, shortest path, and network density (Bao et al. 2018; Knox et al. 2011; Liu et al. 2015; Sun et al. 2013), and predict the potential active components and potential target proteins. Secondly, the top 10 protein targets and Ginkgo seeds active components with higher degree were presented. Thirdly, based on this, the compound-target interaction map could be constructed.

Finally, PPI (protein-protein interaction) network was created by importing the gene names of above proteins to the public database STRING (Szklarczyk et al. 2017). To enhance the accuracy of the results, the minimum required interaction score was set at 0.9. Cytoscape 3.2.1 was used as a tool to visualize the PPI network. The size and color of nodes can be used for reflecting the size of the degree of network, and the thickness of the edge is used to reflect the size of the combine score.

\section{BIOLOGICAL FUNCTION AND PATHWAY ANALYSIS}

The molecular functions and metabolic pathways of the potential targets were enriched and analyzed by three common plug-in, the Clue GO (Bindea et al. 2009) plug-in, the KEGG (Kyoto Gene, and Genomic Encyclopedia) in Cytoscape 3.2.1 software. In the software the parameter of species and genera was set to Homo sapiens. At the same time, other screening factors of biological functions and pathways were as follows: The assumed value (P-value) $\leq 0.05$; the kappa score threshold was set to 0.4 ; the rest are set as default parameters. In the network diagram, nodes represent targets, metabolic pathways, and edges represent the relationship between target-pathways.

\section{RESULTS}

\section{ANALYSIS OF MOLECULAR DESCRIPTORS}

Lipinski's rule of five is one of the important features for the development of oral drugs. At present, the 'rule of five' is commonly referred to as a 'druglikeness' guideline in lead optimization. As listed in Table 2, the average number of rotatable bonds was 6.17 (median 5.00); the mean of polar surface area was 58.04; most of the others were acceptable, according to rule of five. These results showed that the components of Ginkgo seeds possessed good physicochemical properties that might lead to their good bioavailability as oral ingredients.

TABLE 2. Molecular descriptors of Ginkgo seeds components

\begin{tabular}{ccccc}
\hline Molecular descriptor & $\begin{array}{c}\text { Minimum } \\
\text { value }\end{array}$ & $\begin{array}{c}\text { Maximum } \\
\text { value }\end{array}$ & Average value & Median \\
\hline Chiral Center Count & 0 & 20.00 & 3.59 & 1.00 \\
MR & 34.60 & 506.00 & 267.74 & 254.25 \\
HBA & 1.00 & 14.00 & 4.63 & 2.00 \\
HBD & 0 & 9.00 & 2.25 & 1.00 \\
RB & 0 & 15.00 & 6.17 & 5.00 \\
MW & 284.48 & 831.91 & 527.20 & 417.79 \\
Ring Count & 0 & 9.00 & 0.51 & 0 \\
PSA & 10.15 & 152.51 & 58.04 & 50.84 \\
Heavy Atom Count & 3.00 & 60.00 & 26.09 & 24.00 \\
AlogP & 1.00 & 19.00 & 10.36 & 5.50 \\
\hline
\end{tabular}

MR: mole refractive index. HBA: H Bond Acceptor. HBO: H Bond Donor. RB: Rotatable Bond. MW: Molecular Weight. PSA: Polar surface area. AlogP: lipo-hydro partition coefficient 


\section{CONSTRUCTION OF GINKGO SEEDS COMPONENTS- TARGET NETWORK}

The components, protein targets, and attribute files were imported into Cytoscape 3.2.1. Cytoscape software can be used to construct the interaction network between Ginkgo seeds components and protein targets of bronchitis. As seen in Figure 2, both the chemical composition and targets are represented by 'node', and the 'edge' of the connection between nodes represented the interaction between the component and the target.

Analysis of the compounds-targets network map can show the topology characteristics of biological network and node. It can be used for mining potential biological information. The overall feature analysis showed that the length of the feature path is 2.296; the shortest path is $12432(100 \%)$; the number of nodes is 112 ; the average number of adjacent nodes is 18.589 ; the network centrality is 0.215 ; the network density is 0.167 , and the network heterogeneity is 0.658 . In this network, we can check many kinds of interaction of multi-component and singletarget protein, single-component and multi-target protein, which was closely related to the characteristics of multicomponent and multi-target synergy of Ginkgo seeds. Betweenness and network degree of nodes are usually used to evaluate the relationship between compounds and target proteins in network graph. Therefore, this study selects the top 10 targets ranked by network degree of nodes. The relationship between the compounds and targets with high docking scores was subsequently analyzed to explain the cooperation of the biological network. The network characteristic values and compound-target protein interaction diagram were displayed in Table 3 and Figure 3. The interactions between compounds and targets were predicted by molecular docking. The binding interaction including hydrogen bonding, $\pi-\pi$ stacking, metal coordination, and cation- $\pi$ binding can be seen clearly. Hydrogen bonds, and $\pi-\pi$ stacking are widely found in macromolecules and ligand complexes, which play an important role in the formation and stability of these structures. The residues of binding sites played important roles in the function of protein structure and receptor-ligand recognition.

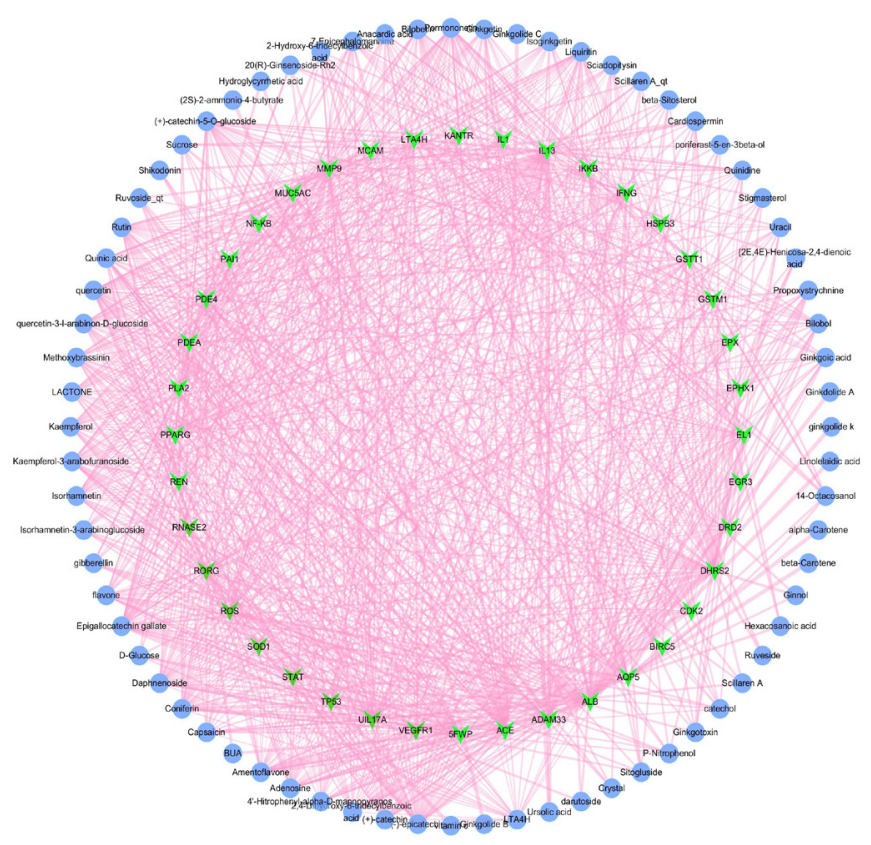

Note: The blue nodes represent the chemical composition of Ginkgo seeds. The green nodes represent the targets associated with bronchitis. The edges represent interaction between the component and the target

FIGURE 2. Network of compounds-targets 
TABLE 3. Network features of partial nodes in Ginkgo seeds component-target network and the Docking score

\begin{tabular}{ccccc}
\hline Node & Betweenness & Network degree & component & Docking score \\
\hline ALB & 0.08468201 & 46 & Amentoflavone & -11.273 \\
DHRS2 & 0.0477495 & 43 & (+)-Catechin-5-O-glucoside & -9.56 \\
IL13 & 0.06353774 & 42 & Liquiritin & -9.061 \\
IL17A & 0.03530803 & 36 & Quercetin-3-L-arabinon-7-D-glucoside & -7.826 \\
ACE & 0.06532964 & 35 & 20(R)-Ginsenoside-Rh2_qt & -7.774 \\
MMP9 & 0.04023315 & 35 & Kaempferol-3-arabofuranoside & -8.898 \\
ROS & 0.02596331 & 35 & $(-)$-Epicatechin & -9.905 \\
PDEA & 0.02411664 & 35 & Rutin & -9.069 \\
ADAM33 & 0.02257872 & 35 & $(+)$-Catechin-5-O-glucoside & -8.283 \\
EL1 & 0.01674952 & 34 & Liquiritin & -9.816 \\
\hline
\end{tabular}

A

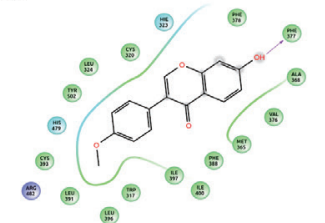

$\mathbf{E}$

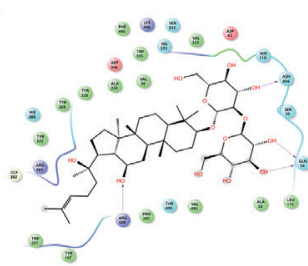

G
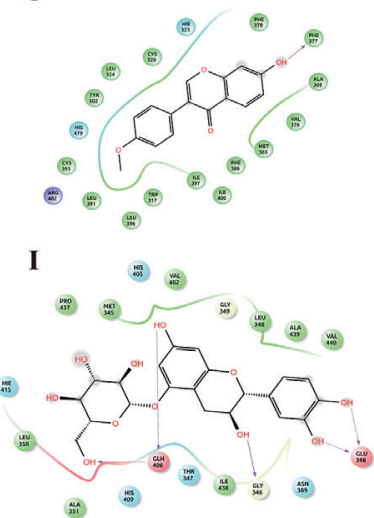

B

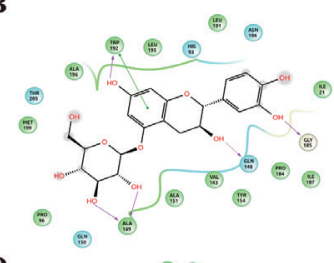

D

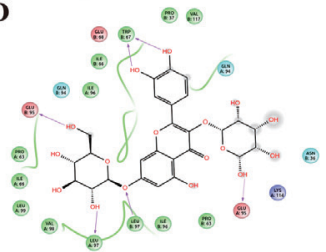

F

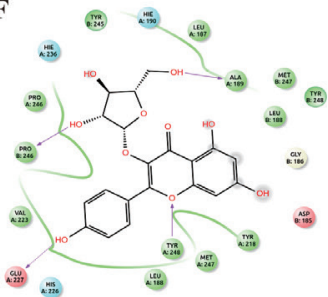

H
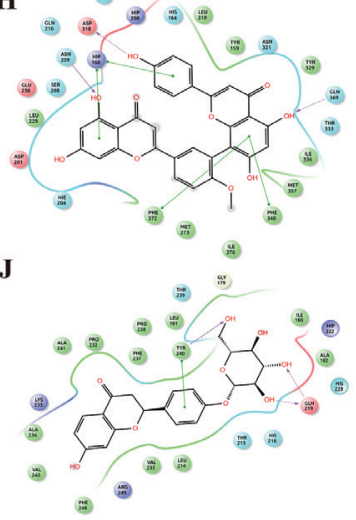

$\mathbf{K}$

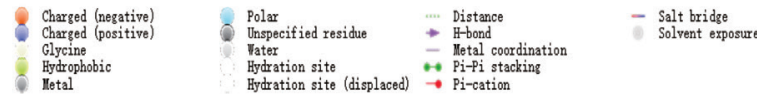

FIGURE 3. Compound-target interaction diagram. A to J represents interaction diagram between different compounds and targets. $\mathrm{K}$ explains what these icons represent. (A) Amentoflavone-ALB. (B) (+)-Catechin-5-O-glucoside-DHRS2. (C) Liquiritin-IL13. (D) Quercetin-3-L-arabinon-7-D-glucoside-IL17A. (E) 20(R)-Ginsenoside-Rh2 qt-ACE. (F) Kaempferol-3-arabofuranoside-MMP9. (G) (-)-Epicatechin-ROS. (H) Rutin-PDEA. (I) (+)-Catechin-5-O-glucoside-ADAM33. (J) Liquiritin-EL1 


\section{CONSTRUCTION OF PROTEINS INTERACTIONS NETWORK}

The 40 potential targets of bronchitis related to Ginkgo seeds active ingredients were imported into the String database. After defining the species as human, the protein interaction relationship between these 40 protein targets was generated. Due to the fact that some proteins do not interact with other proteins, they would not be shown in Figure 4 . The nodes represented proteins, while the edges represented the interrelationships between proteins. It contained 35 nodes and 126 edges in this network. The size and color of the nodes represent the value of the degree. The larger the node was (the color from blue to red), the larger the degree value was. In addition, the size of the interaction score value was represented by the thickness of the edges. The thicker the edge was (the color also from blue to red), the larger the interaction score value was. As can be seen from the diagram, ALB (Albumin) and TP53 (Mutant tumor protein 53) were the two proteins with the highest degrees, indicating greater interaction with other proteins. The content of ALB protein is a commonly used indicator of bronchitis, which can reflect the sputum of patients. TP53 regulates the transcription of DNA repair genes and other related signaling pathways, which have therapeutic effects on pneumonia and bronchial inflammation. Among them, the interactions between TP53 and GSTT1 (Glutathione S-transferase theta 1) or GSTM1 (Glutathione S-transferase M1) were better.

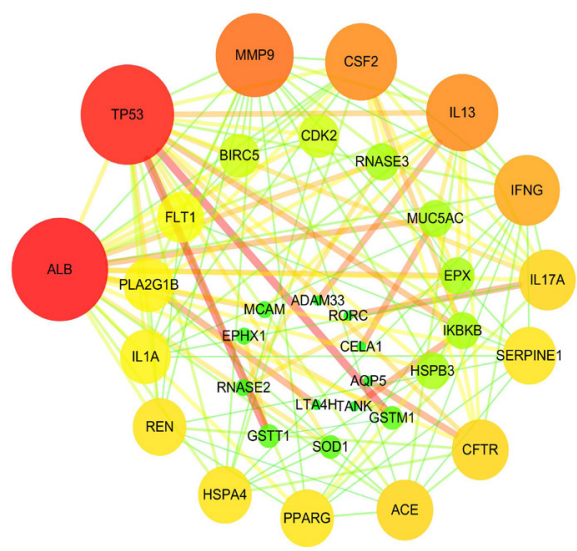

FIGURE 4. Proteins interactions network. The size of the nodes represents the value of the degree. The thickness of the edges represents the interaction score. The larger the nodes were and the thicker the edges were, the larger the degree value and the interaction score were. The color from green to red also represents the larger the degree value and the interaction score were

\section{CHARACTERISTIC ANALYSIS OF TARGET PROTEIN PATHWAY NETWORK}

Based on enrichment analysis of metabolic pathways, targets with similar biological functions can be clustered as new biological functional modules. The biological functions and metabolic pathways of potential targets were analyzed by Clue GO plug-in, as shown in Figure 5. The biological functions of bronchitis protein targets related to Ginkgo seeds were mainly enriched in five aspects: 3', 5 '-cyclic-nucleotide phosphodiesterase activity, cyclicnucleotide phosphodiesterase activity, monocarboxylic acid binding, chaperone binding, and copper binding activity. Cyclic-nucleotide phosphodiesterase activity plays an important role in the process of airway remodeling. Its inhibitors have the effects of anti-inflammatory, antiplatelet aggregation, and inhibition of smooth muscle cell proliferation, which is expected to be a drug for the treatment of bronchial inflammation (Torphy et al. 1999). Signaling pathways were mainly clustered in 5 aspects: IL-17 signaling pathway, fluid shear stress and atherosclerosis signaling pathway, asthma pathway, renin secretion pathway, P53 signaling pathway. Among them, IL-17 is closely related to airway remodeling. Studies have shown that IL-17 can directly act on airway smooth muscle cells and promote airway smooth muscle proliferation (Chang et al. 2011). 


\section{A}

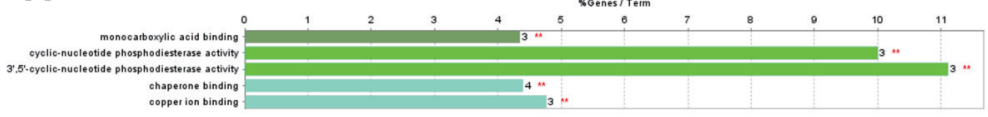

B

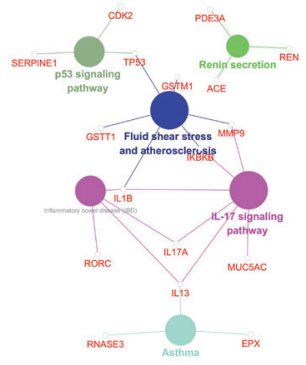

C

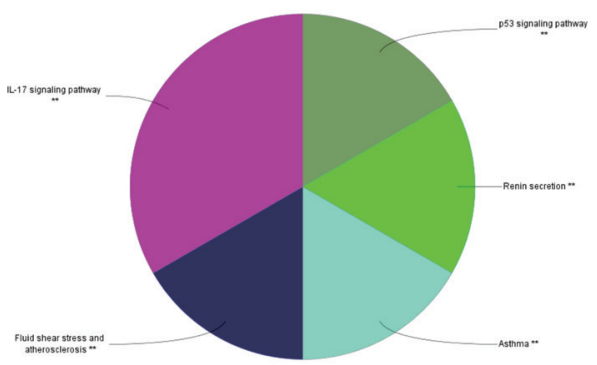

FIGURE 5. Enriched Gene function and KEGG (Kyoto Gene, and Genomic Encyclopedia) pathways of potential targets from main active ingredients of Ginkgo seeds (A) Enrichment of targets' Biological Functions (B, C) Enrichment of targets' metabolic pathways

\section{BIOLOGICAL PROCESS ANALYSIS}

The biological processes of potential targets of bronchitis related to Ginkgo seeds's active ingredients were mainly clustered in eight aspects, as shown in Figure 6. They included lipid transport, positive regulation DNA, sialic acid secretion, embryo implantation, cAMP metabolic process, circadian rhythm regulation, myeloid leukocyte differentiation and other biological processes.

A

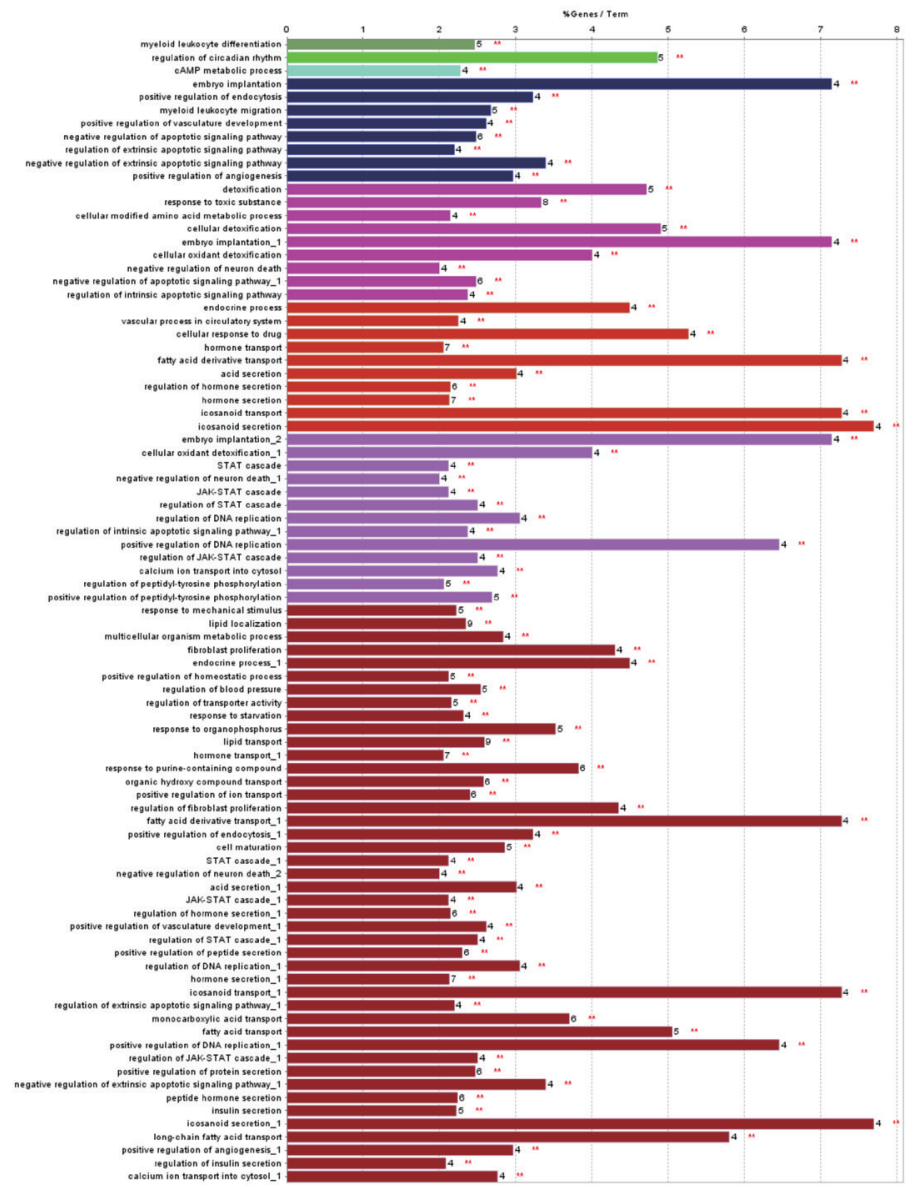


B
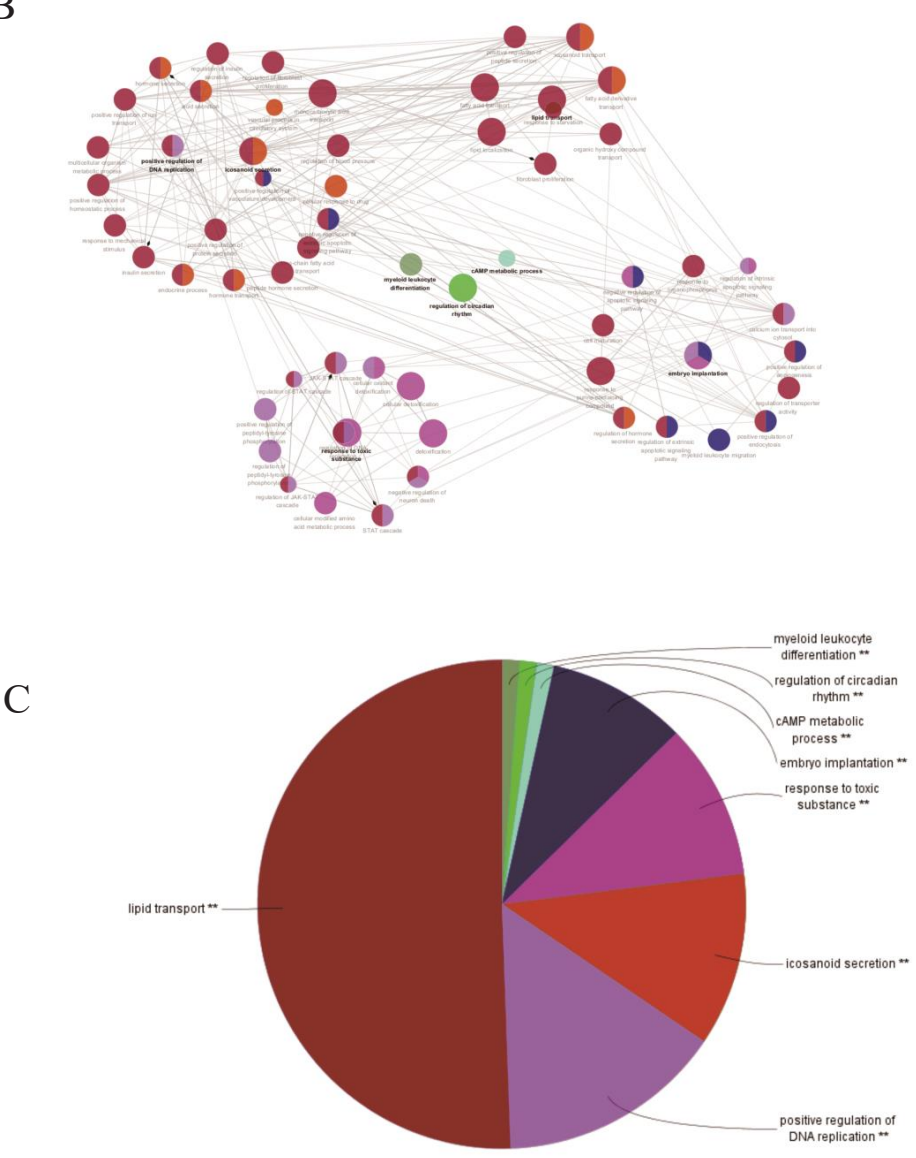

FIGURE 6. Enriched GO biological processes of potential targets from main active ingredients of Ginkgo seeds. A, B, and C are all description of the biological processes involved in the targets. $\mathrm{C}$ is a classification and summary of the first two

\section{DISCUSSION AND CONCLUSION}

Based on molecular docking score, the componentstargets network was rapidly constructed, and the top 10 protein targets of bronchitis were selected by analyzing the characteristics of the network. The mechanism of action of Ginkgo seeds in curing bronchitis would be explained, combining with the related literatures. First, modern medical research has confirmed that platelet aggregation is closely related to asthmatic bronchitis. Platelet activating factor can cause platelet transfer, bronchospasm and airway hyperresponsiveness, and ultimately lead to airway epithelial injury (Nicholson et al. 2000; Pedersen et al. 2005). ALB is a protein that binds endogenous and exogenous substances. It inhibits platelet aggregation. From network analysis, Ginkgo seeds components can regulate ALB protein. Second, IL-13 can mediate the accumulation of eosinophils by activating inflammatory cells. It can also promote the production of IgE, inhibit the differentiation of Th1 cells and induce its differentiation into Th2 cells (Ooi et al. 2012; Sela 1999). In addition, IL-13 can increase airway hyperresponsiveness, promote secretion of bronchial mucus and synthesis of extracellular matrix, enhance the contractile force of airway smooth muscle cells, and take part in the process of airway inflammation and airway remodeling (Wynn 2003). Third, IL-17A is a proinflammatory cytokine that can be expressed in specific lymphocyte subsets. Studies have shown that IL-17A can promote the accumulation of inflammatory cells, especially neutrophils, in the airway through up regulation of IL-8 (Hellings et al. 2003). IL-8, also known as neutrophil like activation protein, is secreted in epithelial cells, and airway smooth muscle cells. 1L-17A can participate in airway inflammation by inducing the activation of neutrophils and collecting eosinophils and basophils (Xiao et al. 2005). Fourth, MMP-9 is an important protease derived from airway inflammatory cells and structural cells to maintain normal matrix metabolism. Recent studies have shown that when the synthesis and secretion of MMP-9 increases in bronchitis patient, it can cause and aggravate airway inflammation and injury, making inflammatory cells transfer or aggregate to the airway epithelium, as well as activating various growth factors in the interstitium and promoting fibroblast proliferation, angiogenesis, and airway remodeling (Nakashima et al. 2006). Finally, phosphodiesterase (PDE) inhibitors can inhibit the hydrolysis of intracellular cAMP involved in the pathophysiological process of asthma and increase the concentration of cAMP, thus, producing a wide range of pharmacological effects. Its 
pharmacological effects mainly involve with the following 2 aspects: extensively inhibiting the activity of immune and inflammatory cells for producing anti-inflammatory effects, and bronchial smooth muscle relaxation. Furthermore, it can restrain mitosis from inhibiting the proliferation and hypertrophy of smooth muscle cells, which may affect the remodeling of respiratory tract in patients with chronic asthma, preventing further deterioration of lung function (Schmidt 1999; Spina et al. 1998). In addition, amentoflavone, (-)-Epicatechin and liquiritin are three important components in Ginkgo seeds. These results would provide a reference for subsequent 'wet' experiments.

The analysis results of protein-protein interaction network showed that the treatment of Ginkgo seeds against bronchitis is not only a single action, and there were plenty of interaction between these targets which consisted of complex network of interaction. Biological function analysis of the targets demonstrated that bronchitis, as a complex disease, involves with many biological processes in the body. It is consistent with the relevant literature.

Based on the analysis of the biological function and metabolic pathway of the target, the biological function of Ginkgo seeds in the treatment of bronchitis could be clustered in five aspects. These functions are closely related to the formation of bronchitis. Five kinds of cellular signaling pathways were identified by constructing a targetmetabolic pathway interaction network. First, the IL-17 signaling pathway relates to the occurrence of various inflammatory diseases, which can promote the release of granulocyte colony-stimulating factor, for instance, IL-8 and other cytokines from airway epithelial cells and fibroblasts. It can also induce and activate neutrophils, and then transfer them into the respiratory tract, participating in respiratory airway hyperresponsiveness, inflammation and airway remodeling. Therefore, IL-17 can mediate local tissue inflammation by bringing the release of various cytokines in bronchitis, especially in airway hyperresponsiveness (AHR), allergic airway inflammation and airway remodeling (Kinyanjui et al. 2013). Second, renin secretion system is an important neuroendocrine system of human physiological function. It can regulate the expression of cytokines, inflammatory chemokines, adhesion molecules and other inflammatory mediators. It can also stimulate the aggregation of inflammatory cells, and participate in the occurrence of inflammation-related diseases. In the renin secretory system, angiotensin II (Ang II) participates in the whole process of inflammation and promotes the infiltration, chemotaxis and tissue repair of inflammatory cells. Most studies have shown that the activation of renin-angiotensin system in the lung tissue of asthmatic rats increases the production of Ang II, thus, causing the hypertrophy of airway smooth muscle and increasing collagen deposition in airway wall by extracellular regulated protein kinase (ERK) and Scr family kinase pathways (Sakai et al. 2010a, 2010b). It plays an important role in airway remodeling. Third, eosinophils (EOS) are important in the expansion of bronchitis. Activated EOS can release many mediators and cytokines, participating in inflammatory reaction, causing airway epithelial injury, and making airway epithelial detachment and airway hyperresponsiveness (Gaga et al. 2010). Finally, P53 signaling pathway is often involved in the regulation of apoptosis. It has been reported that chronic airway inflammation is associated with apoptosis, and apoptosis gene P53 can weaken the expression of EOS in bronchitis (Yoshida et al. 2015). Literature and molecular docking results indicated that network pharmacology predictions have to some extent accuracy. This study fully reflects that Ginkgo seeds can treat bronchitis by means of multi-component, multi-target and multi-pathway. It provides a new idea for further experimental study on the anti-bronchitis mechanism of Ginkgo seeds, especially in determining potential components and targets.

\section{ACKNOWLEDGEMENTS}

This work was supported by the Jiangsu provincial policy guidance program (SZ-XZ2017023), the Qing Lan Project of Jiangsu Province (2017). We declare that there are no competing interests. Lihu Zhang, Dongdong Li and Tao Wu conceived and designed the experiments; Tingting Wu performed the experiments and wrote the paper; Yan Jiang and Linguo Zhao checked the data.

\section{REFERENCES}

Bao, Y.T., Wang, Y., Ren, X.D., Huang, L.F. \& Zeng, R. 2018. Exploration on antibacterial activity and mechanism of flowers and leaves from Paeonia rockii based on network pharmacology. China Journal of Chinese Materia Medica 43(4): 779-785.

Bindea, G., Mlecnik, B., Hackl, H., Charoentong, P., Tosolini, M., Kirilovsky, A., Fridman, W.H., Pages, F., Trajanoski, Z. \& Galon, J. 2009. ClueGO: A Cytoscape plug-in to decipher functionally grouped gene ontology and pathway annotation networks. Bioinformatics 25(8): 1091-1093.

Chang, Y., Al-Alwan, L., Risse, P.A., Roussel, L., Rousseau, S., Halayko, A.J., Martin, J.G., Hamid, Q. \& Eidelman, D.H. 2011. TH17 cytokines induce human airway smooth muscle cell migration. Journal of Allergy Clinical Immunology 127(4): 1046-1053.

Gaga, M., Lambrou, P., Papageorgiou, N., Koulouris, N.G., Kosmas, E., Fragakis, S., Sofios, C., Rasidakis, A. \& Jordanoglou, J. 2010. Eosinophils are a feature of upper and lower airway pathology in non-atopic asthma, irrespective of the presence of rhinitis. Clinical \& Experimental Allergy 30(5): 663-669.

Hellings, P.W., Kasran, A., Liu, Z., Vandekerckhove, P., Wuyts, A., Overbergh, L., Mathieu, C. \& Ceuppens, J.L. 2003. Interleukin-17 orchestrates the granulocyte influx into airways after allergen inhalation in a mouse model of allergic asthma. American Journal of Respiratory Cell and Molecular Biology 28(1): 42-50.

Kinyanjui, M.W., Shan, J., Nakada, E.M., Qureshi, S.T. \& Fixman, E.D. 2013. Dose-dependent effects of IL-17 on IL-13-induced airway inflammatory responses and airway hyperresponsiveness. Journal of Immunology 190(8): 38593868.

Knox, C., Law, V., Jewison, T., Liu, P., Ly, S., Frolkis, A., Pon, A., Banco, K., Mak, C., Neveu, V., Djoumbou, Y., Eisner, 
R., Guo, A.C. \& Wishart, D.S. 2011. DrugBank 3.0: A comprehensive resource for 'omics' research on drugs. Nucleic Acids Research 39(Database issue): D1035-D1041.

Kohl, M., Wiese, S. \& Warscheid, B. 2011. Cytoscape: Software for visualization and analysis of biological networks. Methods in Molecular Biology 696: 291-303.

Li, S.J., Geng, J.L. \& Zhang, Y. 2017. Advances in pharmacological research of Ginkgo biloba. Drug Evaluation Research 40: 731-741.

Liu, Y.F., Ai, N., Keys, A., Fan, X.H. \& Chen, M.J. 2015. Network pharmacology for traditional Chinese medicine research: Methodologies and applications. Chinese Herbal Medicines 7(1): 18-26.

Nakashima, K., Hirota, T., Obara, K., Shimizu, M., Doi, S., Fujita, K., Shirakawa, T., Enomoto, T., Yoshihara, S., Ebisawa, M., Matsumoto, K., Saito, H., Suzuki, Y., Nakamura, Y. \& Tamari, M. 2006. A functional polymorphism in MMP-9 is associated with childhood atopic asthma. Biochemical \& Biophysical Research Communications 344(1): 300-307.

Nicholson, J.P., Wolmarans, M.R. \& Park, G.R. 2000. The role of albumin in critical illness. British Journal of Anaesthesia 85(4): 599-610.

Ooi, A.T., Ram, S., Kuo, A., Gilbert, J.L., Yan, W., Pellegrini, M., Nickerson, D.W., Chatila, T.A. \& Gomperts, B.N. 2012. Identification of an interleukin 13-induced epigenetic signature in allergic airway inflammation. American Journal of Translational Research 4(2): 219-228.

Pedersen, T., Møller, A.M. \& Gøtzsche, P.C. 2005. Human albumin in critically ill patients. Critical Care Medicine 33(5): 1183-1185.

Ru, J., Li, P., Wang, J., Zhou, W., Li, B., Huang, C., Li, P., Guo, Z., Tao, W., Yang, Y., Xu, X., Li, Y., Wang, Y. \& Yang, L. 2014. TCMSP: A database of systems pharmacology for drug discovery from herbal medicines. Journal of Cheminformatics 6(1): 13 .

Sakai, H., Nishimura, A., Watanabe, Y., Nishizawa, Y., Hashimoto, Y., Chiba, Y. \& Misawa, M. 2010a. Involvement of Src family kinase activation in angiotensin II-induced hyperresponsiveness of rat bronchial smooth muscle. Peptides 31(12): 2216-2221.

Sakai, H., Nishizawa, Y., Nishimura, A., Chiba, Y., Goto, K., Hanazaki, M. \& Misawa, M. 2010b. Angiotensin II induces hyperresponsiveness of bronchial smooth muscle via an activation of p42/44 ERK in rats. Pflügers Archiv European Journal of Physiology 460(3): 645-655.

Sela, B. 1999. Interleukin IL-13: A central mediator in allergic asthma. Harefuah 137(7-8): 317-319.

Schmidt, D., Dent, G. \& Rabe, K.F. 1999. Selective phosphodiesterase inhibitors for the treatment of bronchial asthma and chronic obstructive pulmonary disease. Clinical \& Experimental Allergy 29(Suppl 2): 99-109.

Spina, D., Landells, L.J. \& Page, C.P. 1998. The role of theophylline and phosphodiesterase4 isoenzyme inhibitors as anti-inflammatory drugs. Clinical \& Experimental Allergy Journal of the British Society for Allergy \& Clinical Immunology 28(Suppl 3): 24-34.

Stover, N.A. \& Cavalcanti, A.R.O. 2014. Using NCBI BLAST. Current Protocols Essential Laboratory Techniques 8(1): 31-35.

Sun, Y., Zhu, R., Ye, H., Tang, K., Zhao, J., Chen, Y., Liu, Q. \& Cao, Z. 2013. Towards a bioinformatics analysis of anti-Alzheimer's herbal medicines from a target network perspective. Briefings in Bioinformatics 14(3): 327-343.
Szklarczyk, D., Morris, J.H., Cook, H., Kuhn, M., Wyder, S., Simonovic, M., Santos, A., Doncheva, N.T., Roth, A., Bork, P., Jensen, L.J. \& Mering, C.v. 2017. The STRING database in 2017: Quality-controlled protein-protein association networks, made broadly accessible. Nucleic Acids Research 45(Database issue): D362-D368.

Torphy, T.J., Barnette, M.S., Underwood, D.C., Griswold, D.E., Christensen, S.B., Murdoch, R.D., Nieman, R.B. \& Compton, C.H. 1999. Ariflo (SB 207499), a second generation phosphodiesterase 4 inhibitor for the treatment of asthma and COPD: From concept to clinic. Pulmonary Pharmacology \& Therapeutics 12(2): 131-135.

Westerhoff, H.V. 2015. Network-based pharmacology through systems biology. Drug Discovery Today Technologies 15 5-16.

Wynn, T.A. 2003. IL-13 effector functions. Annual Review of Immunology 21: 425-456.

Xiao, W., Hsu, Y.P., Ishizaka, A., Kirikae, T. \& Moss, R.B. 2005. Sputum cathelicidin, urokinase plasminogen activation system components, and cytokines discriminate cystic fibrosis, COPD, and asthma inflammation. Chest 128(4): 2316-2326.

Yoshida, Y., Shimizu, I., Katsuumi, G., Jiao, S., Suda, M., Hayashi, Y. \& Minamino, T. 2015. P53-induced inflammation exacerbates cardiac dysfunction during pressure overload. Journal of Molecular and Cellular Cardiology 85: 183-198.

Zhang, L.H., et al. 2018. Prediction of anti-inflammatory mechanism of ginkgo folium extract based on molecular docking and network pharmacology. Chinese Journal of Experimental Traditional Medical Formulae 7: 192-198.

Zhang, X., Gao, Y., Xiang, H., Qin, M.Q. \& Tian, J.S. 2017. An exploration on mechanism of antidepression of Jiaotai Pills based on network pharmacology. Chinese Traditional and Herbal Drugs 48(8): 1584-1590.

Zhu, F., Shi, Z., Qin, C., Tao, L., Liu, X., Xu, F., Zhang, L., Song, Y., Liu, X., Zhang, J., Han, B., Zhang, P. \& Chen, Y. 2012. Therapeutic target database update 2012: A resource for facilitating target-oriented drug discovery. Nucleic Acids Research 40(Database issue): D1128-D1136.

Zhuang, Y., Qin, K., Yang, B., Liu, X., Cai, B. \& Cai, H. 2018. Prediction of the targets of the main components in blood after oral administration of: Xanthii Fructus: A network pharmacology study. RSC Advances 8(16): 8870-8877.

Tingting Wu, Lihu Zhang, Dongdong Li, Tao Wu \& Linguo Zhao* Co-Innovation Center for Sustainable Forestry in Southern China Nanjing Forestry University

159 Long Pan Road

Nanjing 210037

China

Tingting Wu, Lihu Zhang, Dongdong Li, Tao Wu, Yan Jiang* \& Linguo Zhao*

College of Chemical Engineering

Nanjing Forestry University

159 Long Pan Road

Nanjing 210037

China

*Corresponding author; email: jiangyancpu@126.com

Received: 26 June 2020

Accepted: 25 September 2020 